\title{
Constraints on surface seawater oxygen isotope change between the Last Glacial Maximum and the Late Holocene
}

\author{
C. Waelbroeck ${ }^{\text {a, }}{ }^{*}$, T. Kiefer ${ }^{\text {b }}$, T. Dokken ${ }^{\text {c }}$, M.-T. Chen ${ }^{\text {d, H.J. Spero }}{ }^{\text {e }}$, S. Jung ${ }^{f}$, M. Weinelt ${ }^{g}$, \\ M. Kucera ${ }^{\mathrm{h}}$, A. Paul ${ }^{\mathrm{h}}$, on behalf of MARGO Project Members \\ ${ }^{a}$ LSCE/IPSL, Laboratoire CNRS-CEA-UVSQ 91198 Gif-sur-Yvette, France \\ b PAGES International Project Office, 3012 Bern, Switzerland \\ ${ }^{c}$ Uni Research Climate and Bjerknes Centre for Climate Research, Allegaten 55, 5007 Bergen, Norway \\ ${ }^{\mathrm{d}}$ Institute of Applied Geosciences, National Taiwan Ocean University, Keelung 20224, Taiwan \\ e Department Earth and Planetary Sciences, University of California Davis, Davis, CA 95616, USA \\ ${ }^{\mathrm{f}}$ Grant Institute, University of Edinburgh, Edinburgh EH9 3JW, UK \\ ${ }^{\mathrm{g}}$ Institute for Geosciences, University of Kiel, 24098 Kiel, Germany \\ ${ }^{\mathrm{h}}$ MARUM - Center for Marine Environmental Sciences and Department of Geosciences, University Bremen, 28334 Bremen, Germany
}

\section{A R T I C L E I N F O}

\section{Article history:}

Received 23 May 2014

Received in revised form

15 September 2014

Accepted 26 September 2014

Available online 17 October 2014

\section{Keywords}

Paleoceanography

Surface water oxygen isotopic ratio

Planktonic foraminifers

Last Glacial Maximum

\begin{abstract}
A B S T R A C T
Estimates of the change in surface seawater $\delta^{18} \mathrm{O}\left(\delta^{18} \mathrm{O}_{\mathrm{sw}}\right)$ between the Last Glacial Maximum (LGM) and Late Holocene $(\mathrm{LH})$ are derived from homogenous data sets with rigorous age control, namely MARGO sea surface temperature (SST) estimates and oxygen isotopic ratios $\left(\delta^{18} \mathrm{O}\right)$ of planktonic foraminifers. Propagation of uncertainties associated with each proxy allows the identification of robust patterns of change in $\delta^{18} \mathrm{O}_{\mathrm{sw}}$. Examination of these patterns on a regional scale highlights which changes in surface currents and hydrological cycle are consistent with both planktonic isotopic data and reconstructed SST. Positive local annual mean LGM-LH $\delta^{18} \mathrm{O}_{\mathrm{sw}}$ anomalies characterize the glacial tropical Indian Ocean, portions of the western and eastern margins of the North Pacific, the Iberian margin and the tropical North Atlantic, as well as the South African margin. Although reduced precipitation during the LGM with respect to the LH may have contributed to some extent to these local enrichments in surface seawater ${ }^{18} \mathrm{O}$, the largest positive anomalies appear to be related to changes in ocean circulation. Large local negative annual mean LGM-LH $\delta^{18} \mathrm{O}_{\mathrm{sw}}$ anomalies are found in the South Pacific and North Atlantic, reflecting the equatorward migration of surface temperature fronts during the LGM with respect to the LH. In the northern North Atlantic, a region characterized by large discrepancies between SST estimates based on different proxies, only SST estimates based on planktonic foraminifer counts yield annual mean LGM-LH $\delta^{18} \mathrm{O}_{\mathrm{sw}}$ anomalies consistent with a southward shift of the polar front at the LGM relative to the LH.
\end{abstract}

() 2014 Elsevier Ltd. All rights reserved.

\section{Introduction}

Given the large amount of well-dated paleoclimatic data existing for the Last Glacial Maximum (LGM), this time interval is a good target to constrain climate sensitivity and evaluate the capability of models to simulate a climate that is drastically different from the present one (e.g. Braconnot et al. (2012)). Environmental proxy data have been compiled in several projects aimed at reconstructing LGM surface conditions (e.g. Bartlein et al. (2011); MARGO P. M. (2009)). The Multiproxy Approach for the Reconstruction of the Glacial Ocean surface (MARGO) project produced a reassessment of

\footnotetext{
* Corresponding author.
}

LGM sea surface temperatures (SST) (Kucera et al., 2005a; MARGO P. M., 2009). However, changes in SST are not sufficient to fully describe the changes in surface ocean conditions, as changes in surface water salinity are equally important in determining surface water density, and hence deep-water formation processes and ocean circulation. Although quantitative reconstructions of past sea surface salinity (e.g. Duplessy et al. (1991)) are subject to large uncertainties (Rohling and Bigg, 1998), there is a positive correlation between surface seawater oxygen isotopic ratios $\left(\delta^{18} \mathrm{O}_{\mathrm{sw}}\right)$ and salinity that directly results from Rayleigh fractionation processes during evaporation and condensation (Epstein and Mayeda, 1953). Changes in $\delta^{18} \mathrm{O}_{\mathrm{sw}}$ can thus be interpreted in terms of changes in land-based ice volume, river runoff, local precipitation-evaporation budget, or surface oceanic currents. 
In addition to a global synthesis of LGM multiproxy SST estimates (MARGO P. M., 2009), the MARGO project also compiled global datasets of planktonic foraminifer oxygen isotopic ratios $\left(\delta^{18} \mathrm{O}_{\mathrm{c}}\right)$ for the Late Holocene (LH) (Waelbroeck et al., 2005) and LGM (this study, supplementary Table S1). MARGO datasets are characterized by a rigorous definition of the LGM and LH chronozones, i.e. 19-23 cal ky BP (ka) and 0-4 ka, accompanied by an assessment of uncertainty (or chronozone quality levels) (Kucera et al., 2005a).

Here we combine MARGO planktonic foraminifer $\delta^{18} \mathrm{O}_{\mathrm{c}}$ data and SST estimates to derive regional estimates of the change in surface seawater $\delta^{18} \mathrm{O}_{\text {sw }}$ between the LGM and LH. The present study thereby provides the first set of LGM-LH seawater $\delta^{18} \mathrm{O}_{\text {sw }}$ LGM-LH anomalies computed in a systematic way from homogenous data sets with rigorous age control. Furthermore, examination of the estimated LGM-LH $\delta^{18} \mathrm{O}_{\mathrm{sw}}$ anomalies on a regional scale highlights which changes in surface currents and hydrological cycle are consistent with both planktonic isotopic data and reconstructed SST.

\section{Material and methods}

We computed LGM-LH $\delta^{18} \mathrm{O}_{\mathrm{sw}}$ anomalies in 119 sites where both planktonic foraminifer $\delta^{18} \mathrm{O}_{\mathrm{c}}$ and SST anomalies are available (Fig. 1). In some cores, planktonic foraminifer $\delta^{18} \mathrm{O}_{\mathrm{c}}$ data are available for multiple species, yielding a total of $136 \mathrm{LGM}-\mathrm{LH} \delta^{18} \mathrm{O}_{\mathrm{sw}}$ anomaly estimates. Among those, we only discuss and plot significant $\delta^{18} \mathrm{O}_{\text {sw }}$ anomalies (i.e. anomalies larger than the corresponding computed propagated 1 sigma error), i.e. $121 \delta^{18} \mathrm{O}_{\mathrm{sw}}$ anomaly estimates from 110 sites (Figs. 2-4).

\subsection{Planktonic $\delta^{18} \mathrm{O}_{c}$ anomalies}

MARGO LGM planktonic $\delta^{18} \mathrm{O}_{\mathrm{c}}$ dataset (this study) consists of data from 243 deep-sea cores with thorough age control that has been checked for internal consistency (supplementary Table S1). MARGO LGM planktonic $\delta^{18} \mathrm{O}_{\mathrm{c}}$ data were attributed LGM chronozone quality levels of $1-4$, as defined in Kucera et al. (2005a), with the LGM interval extended from $21 \mathrm{ka} \pm 2 \mathrm{ky}$ to $21 \mathrm{ka} \pm 3 \mathrm{ky}$ in
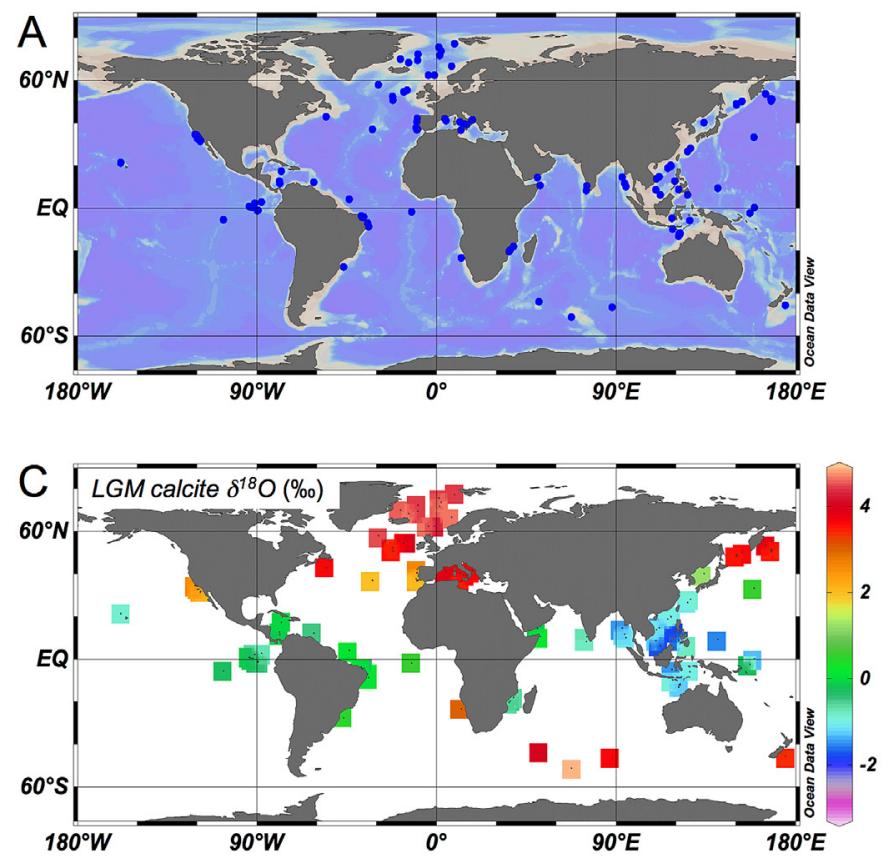

certain cases, in order to maximize geographical coverage. The LH planktonic $\delta^{18} \mathrm{O}_{\mathrm{c}}$ data are from the previously published MARGO LH planktonic $\delta^{18} \mathrm{O}_{\mathrm{c}}$ dataset (Waelbroeck et al., 2005) to which we added 11 new LH planktonic $\delta^{18} \mathrm{O}_{\mathrm{c}}$ data points in key sites (supplementary Table S2). In the present study, we only retain cores with high LGM and LH chronozone quality levels (i.e. levels 1 to 3 for LGM samples, and 1 to 4 for LH samples according to Kucera et al. (2005a) in which both LGM and LH planktonic $\delta^{18} \mathrm{O}_{\mathrm{c}}$ data were available from the same planktonic foraminifer species. At each site, we computed LGM-LH calcite $\delta^{18} \mathrm{O}_{\mathrm{c}}$ anomalies for all species for which $\delta^{18} \mathrm{O}_{\mathrm{c}}$ data were available, i.e. Globigerinoides sacculifer, Globigerinoides ruber (white), Globigerina bulloides, and Neogloboquadrina pachyderma (left).

\subsection{SST anomalies}

Following the approach adopted in (MARGO P. M., 2009), LGMLH SST anomalies are defined as the difference between LGM SST estimates and World Ocean Atlas SSTs. MARGO proxy-specific LGM SST estimates were derived from two types of proxies: microfossilbased (transfer functions based on planktonic foraminifer, diatom, dinoflagellate cyst and radiolarian abundances) and geochemical (alkenones and planktonic foraminifer $\mathrm{Mg} / \mathrm{Ca}$ ) proxies. The use of a common data set of ambient temperatures at $10 \mathrm{~m}$ water depth for the calibration of all proxies (Kucera et al., 2005a) makes MARGO proxy-specific LGM SST estimates easily inter-comparable. At each site, MARGO multiproxy SST estimates were obtained by careful combination of the estimates yielded by different proxies, taking into account the error of the calibration for each proxy, the number of samples per core on which the LGM SST estimate is based, the quality of the age model for each core, and the uncertainty due to the calibration error for each proxy (MARGO P. M., 2009). The final $5^{\circ} \times 5^{\circ}$ MARGO LGM multiproxy SST field was obtained by combining multiproxy SST estimates within each grid cell, taking into account the degree of convergence among the SST estimates within each grid cell (MARGO P. M., 2009).

In the present study, we use MARGO LGM-LH SST proxy-specific anomalies when available. In addition, we interpolated MARGO
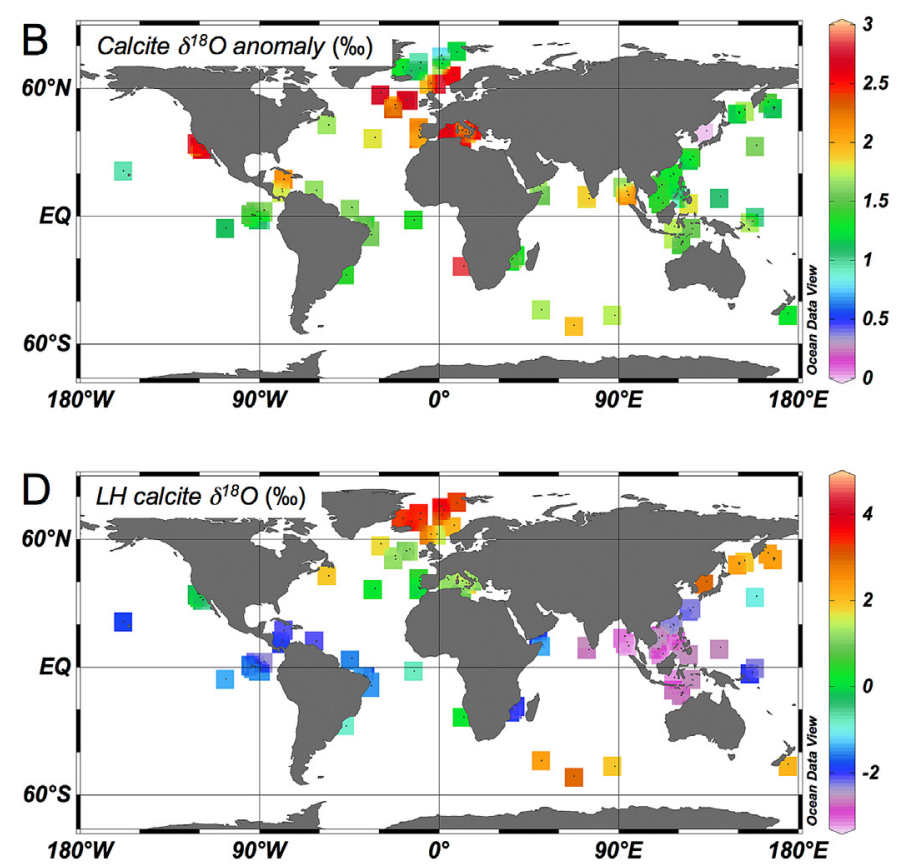

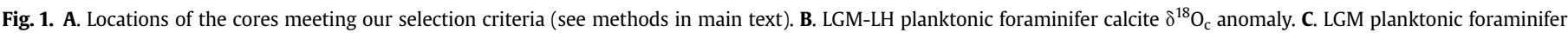
$\delta^{18} \mathrm{O}_{\mathrm{c}}$ (this study). D. LH planktonic foraminifer $\delta^{18} \mathrm{O}_{\mathrm{c}}$ (Waelbroeck et al., 2005). 
A1.

SST anomaly $\left({ }^{\circ} \mathrm{C}\right)$

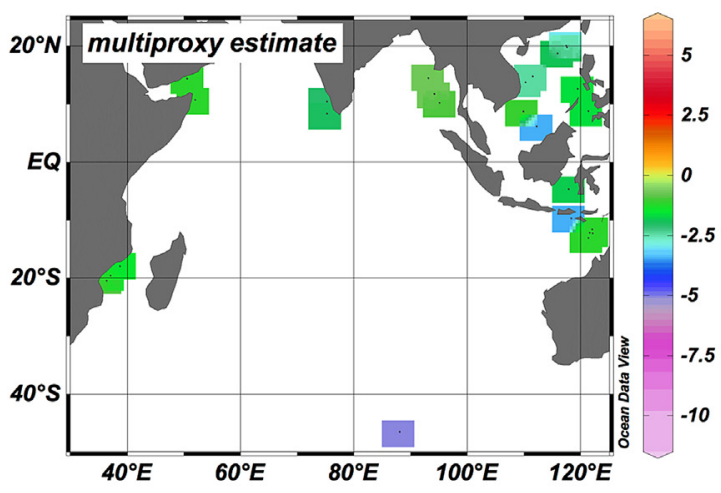

B1.

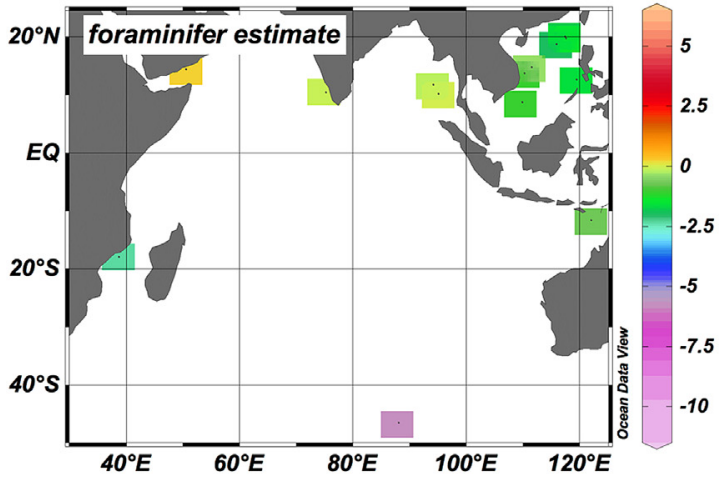

C1.

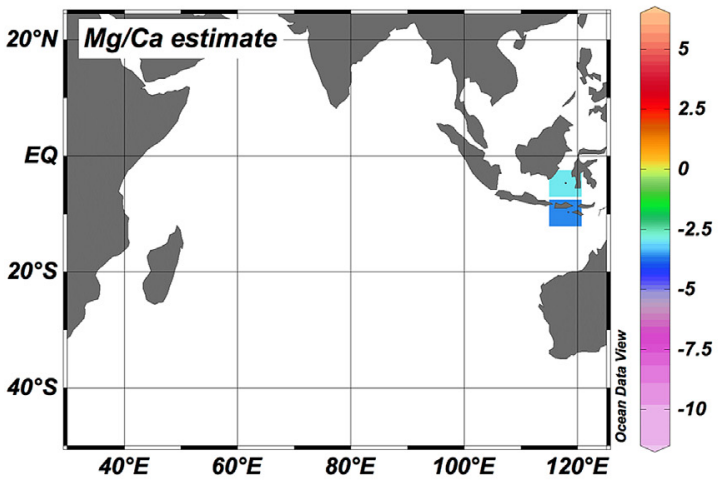

D1.

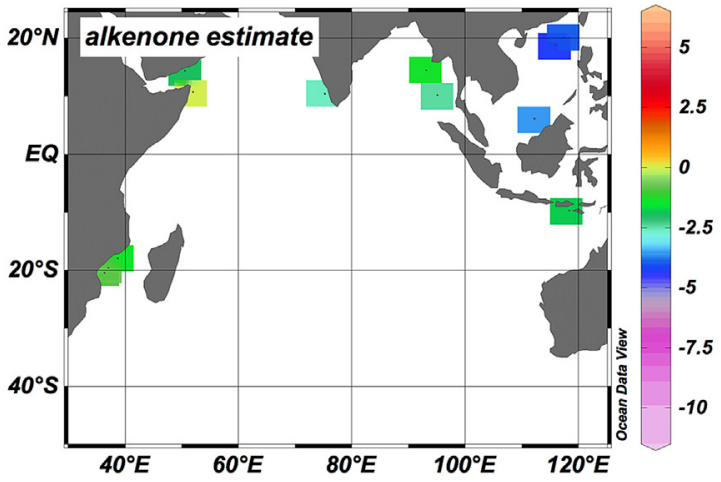

A2. Residual $\delta^{18} O_{s w}$ anomaly (\%)

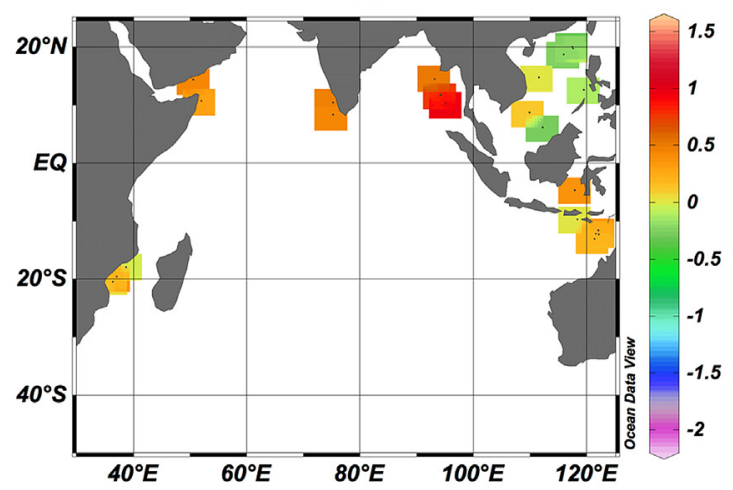

$B 2$.

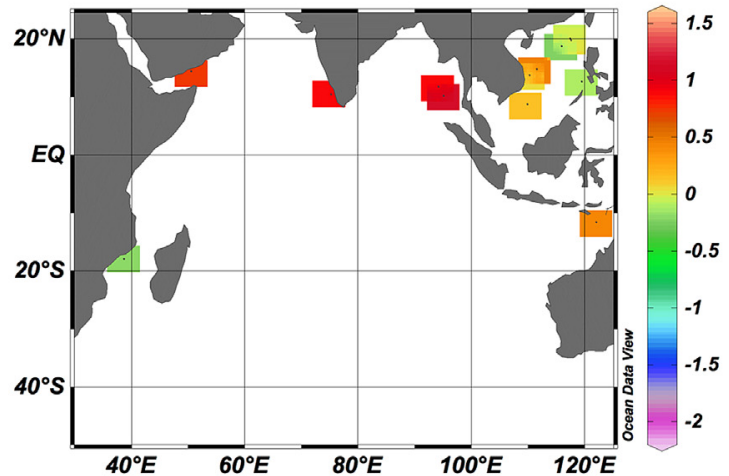

C2.

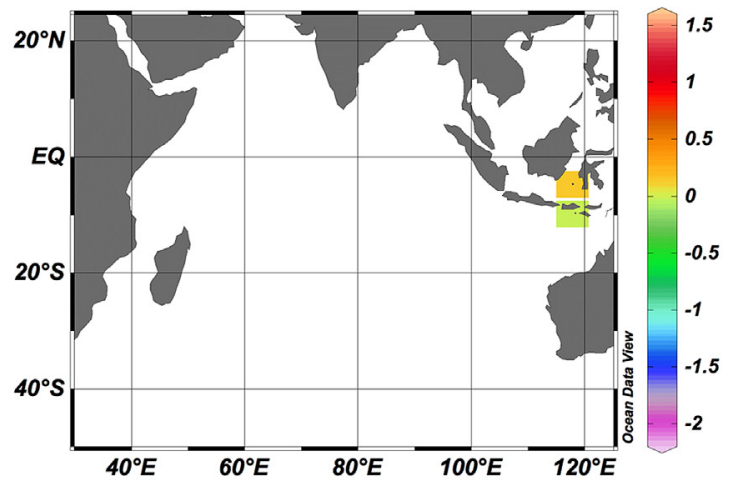

D2.

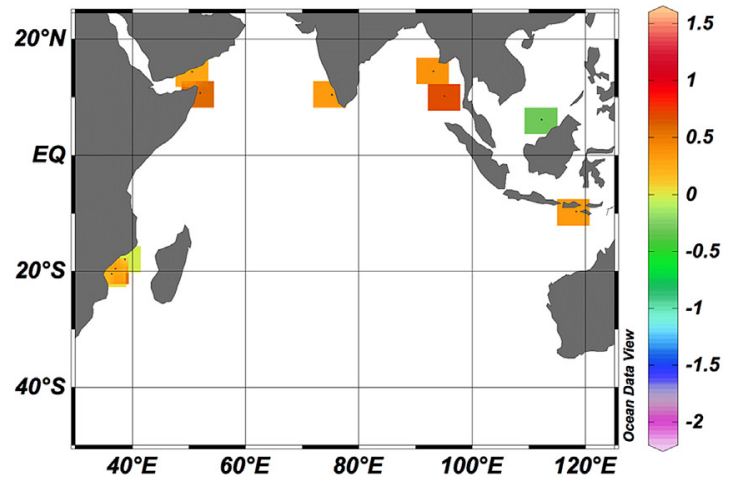

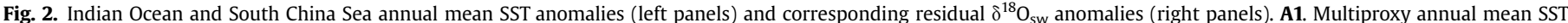

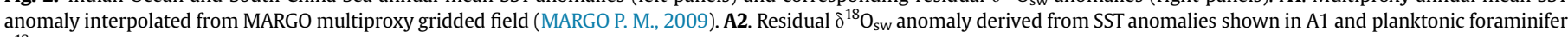

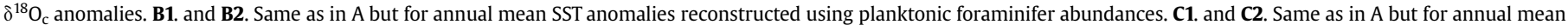
SST anomalies derived from planktonic foraminifer $\mathrm{Mg} / \mathrm{Ca}$. D1. and D2. Same as in A but for annual mean SST anomalies derived from alkenone $\mathrm{U}^{\mathrm{K}}{ }_{37}$. 
A1.

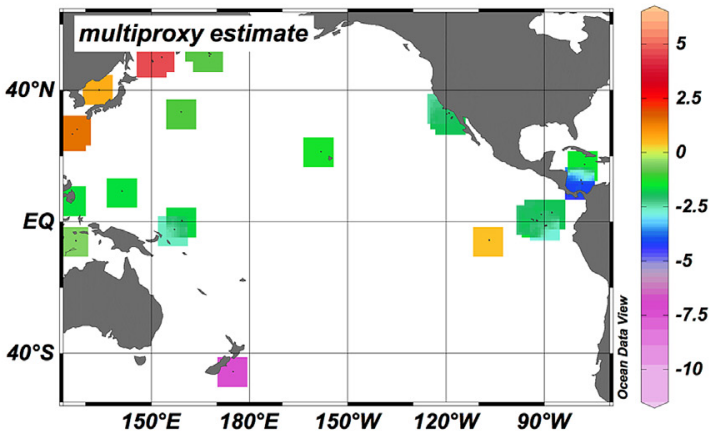

B1.

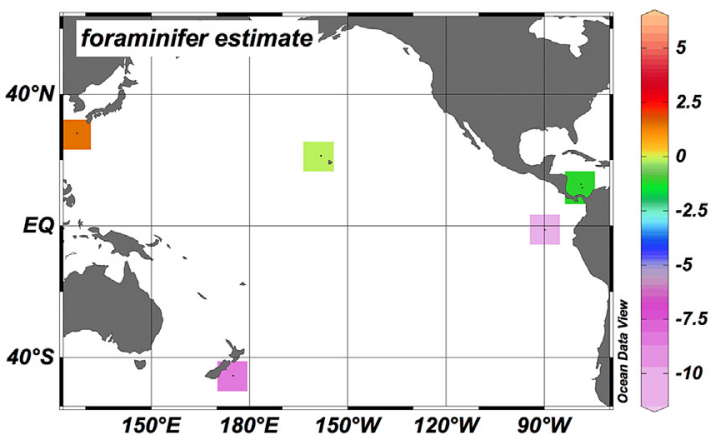

c1.

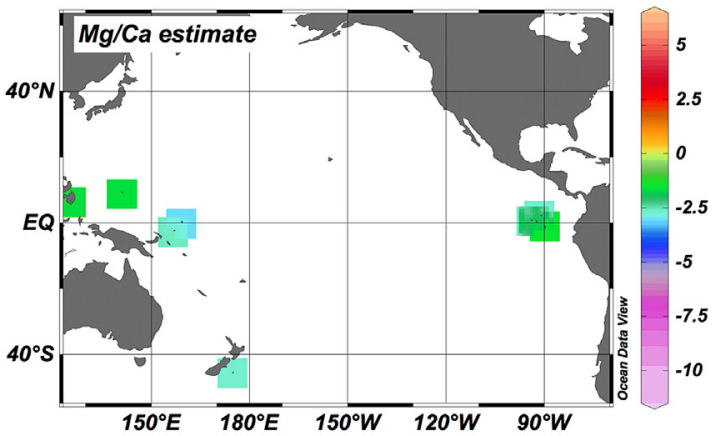

D1.

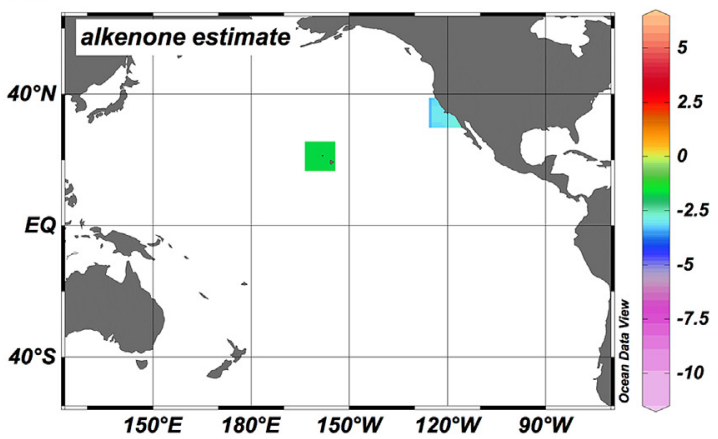

A2. Residual $\delta^{18} O_{s w}$ anomaly (\%o)

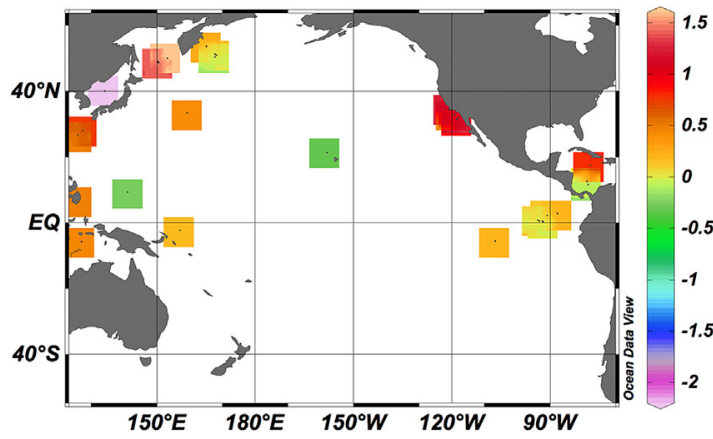

B2.

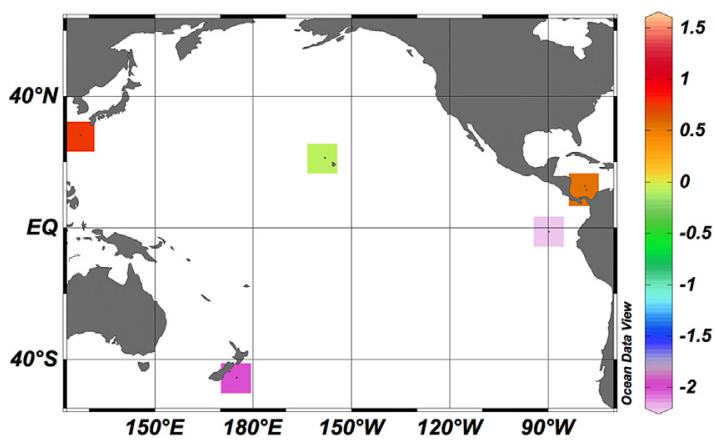

C2.

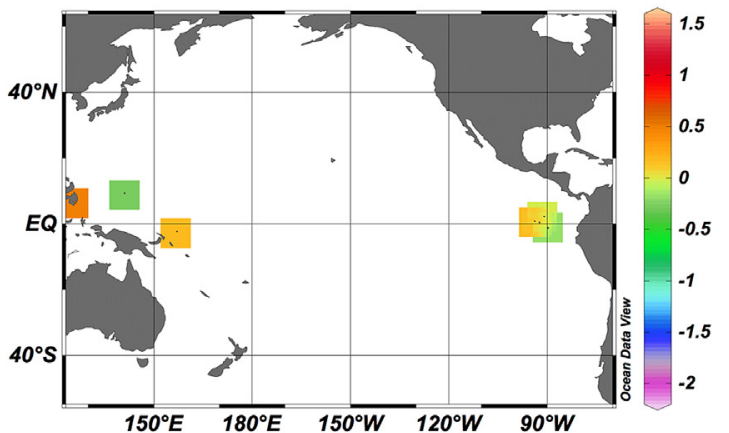

D2.

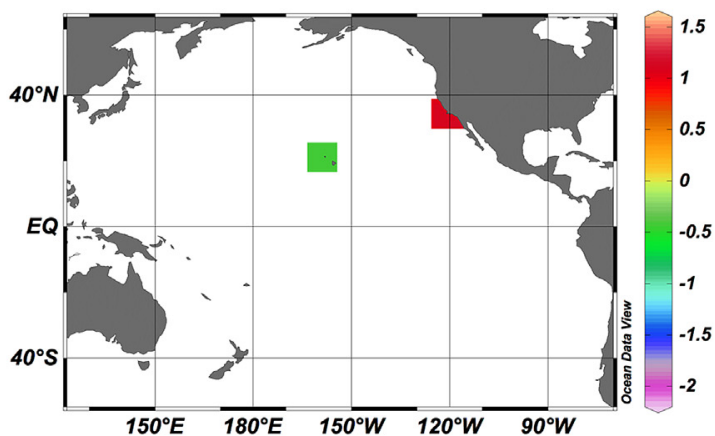

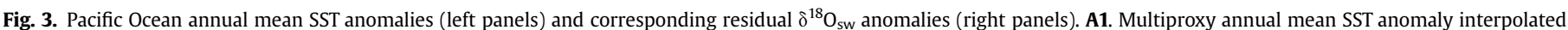

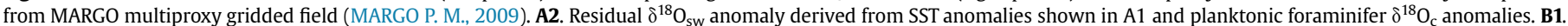

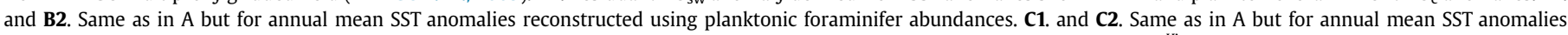
derived from planktonic foraminifer $\mathrm{Mg} / \mathrm{Ca}$. D1. and D2. Same as in A but for annual mean SST anomalies derived from alkenone $\mathrm{U}^{\mathrm{K}}{ }_{37}$ 
A1.

\section{SST anomaly $\left({ }^{\circ} \mathrm{C}\right)$}

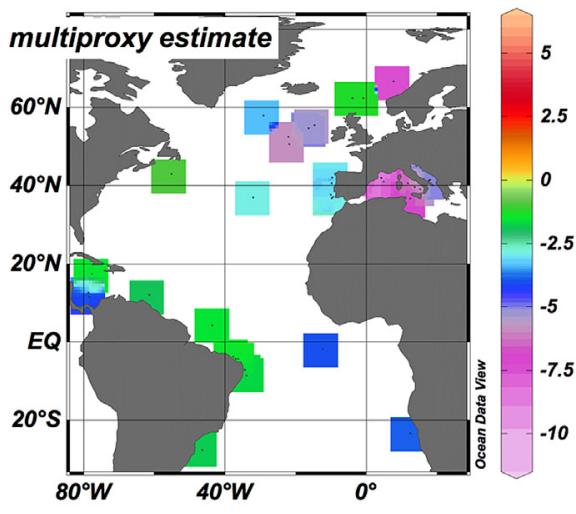

B1.

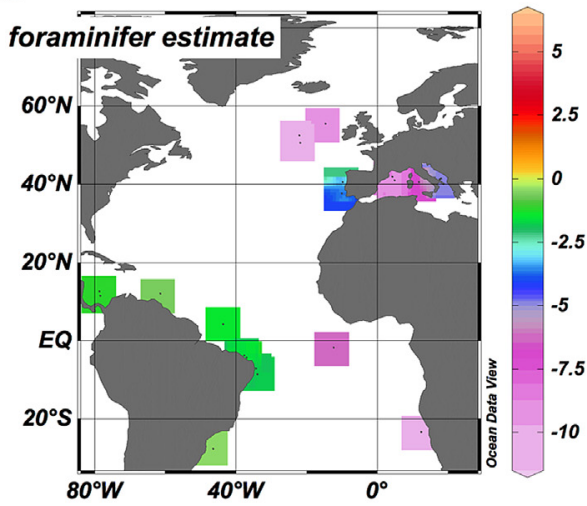

C1.

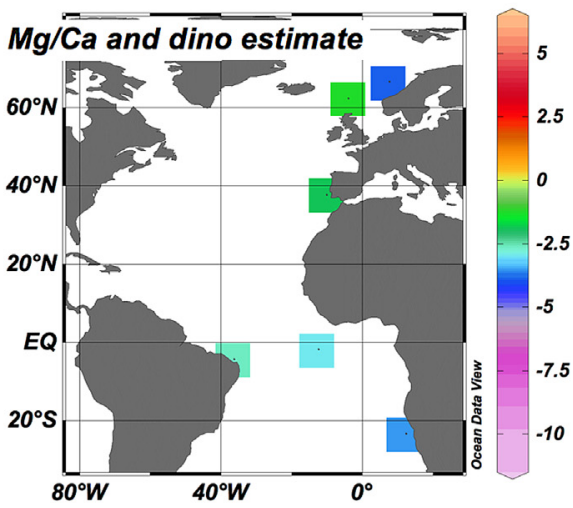

D1.

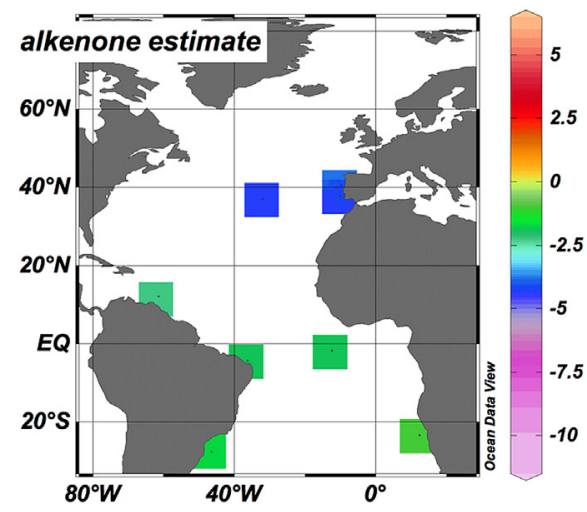

A2.

\section{Residual $\delta^{18} O_{s w}$ anomaly (\%o)}

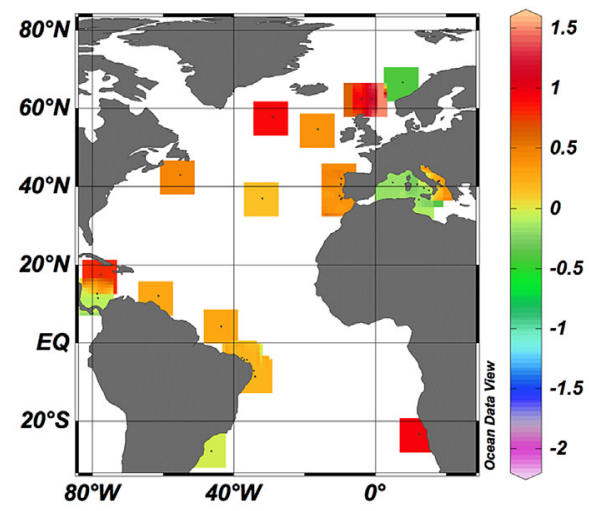

B2.

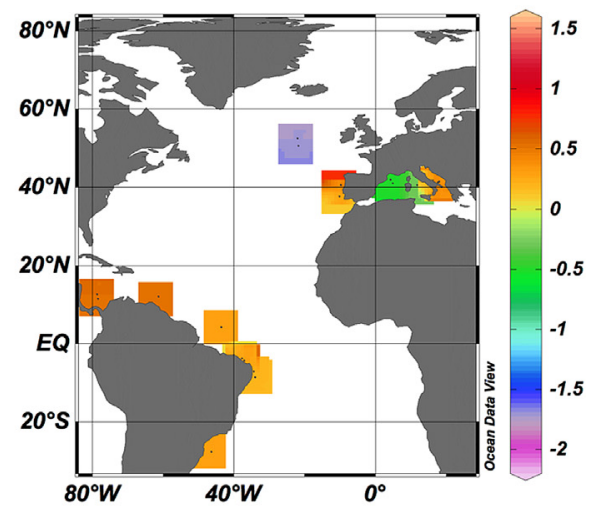

C2.

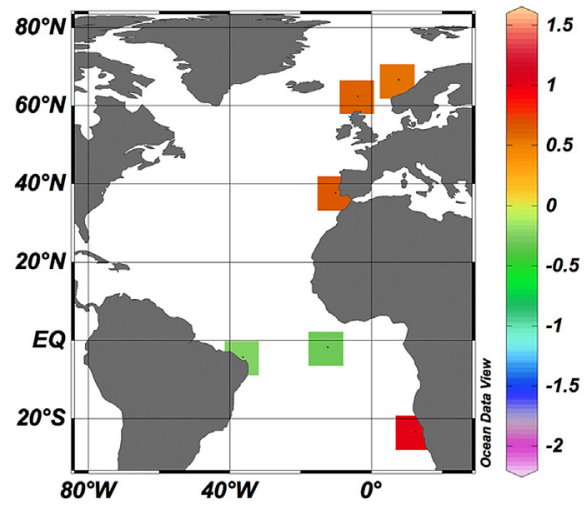

D2.

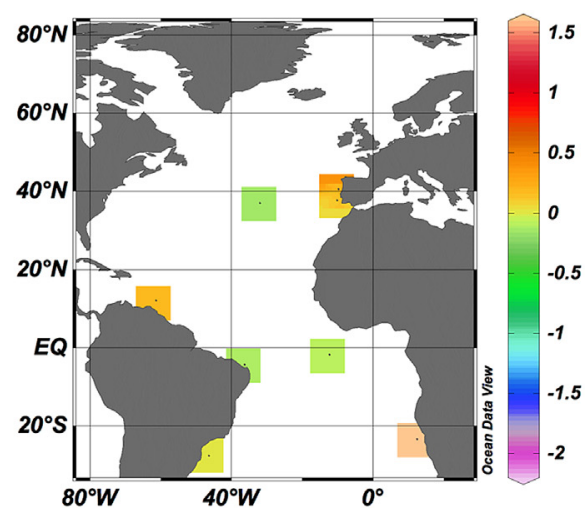


multiproxy gridded field in order to derive SST anomaly estimates at each site from the surrounding four grid nodes, and compare them with proxy-specific estimates where the latter are available.

\subsection{Seawater $\delta^{18} \mathrm{O}_{s w}$ anomalies}

The temperature dependence of the equilibrium fractionation between calcite and water $\delta^{18} \mathrm{O}$ links foraminifer calcite $\delta^{18} \mathrm{O}_{\mathrm{c}}$ to the temperature of the water in which shell precipitation takes place (O'Neil et al., 1969; Kim and O'Neil, 1997). In the present study we use the quadratic approximation of the (O'Neil et al., 1969) equation given in (Shackleton, 1974) to derive $\delta^{18} \mathrm{O}_{\mathrm{sw}}$ from foraminifer $\delta^{18} \mathrm{O}_{\mathrm{c}}$ data and SST estimates. We directly calculate LGM-LH $\delta^{18} \mathrm{O}_{\mathrm{sw}}$ anomalies from calcite $\delta^{18} \mathrm{O}_{\mathrm{c}}$ and SST anomalies. In this way, we minimize the dependence of the results on $\mathrm{LH} \delta^{18} \mathrm{O}_{\mathrm{sw}}$ data (see Supplementary material), which are poorly constrained in some areas (Schmidt et al., 1999).

We assume that MARGO LGM-LH temperature anomalies at $10 \mathrm{~m}$ water depth may be considered a reasonable estimate of LGMLH calcification temperature anomalies of the different planktonic foraminifer species used in this study. We are aware that the extent to which this assumption is valid is extremely difficult to ascertain. Moreover, in order to derive LGM-LH $\delta^{18} \mathrm{O}_{\text {sw }}$ anomalies, we combine planktonic foraminifer $\delta^{18} \mathrm{O}_{\mathrm{c}}$ data with different SST estimates yielded by proxies that are sensitive to different seasons and water depths than planktonic foraminifers. Also, growing season and habitat depths of the different proxy carriers might have changed through time (Fraile et al., 2009; Rosell-Melé and Prahl, 2013) and transfer functions calibrated against near-surface temperatures might not remain valid through time (Telford et al., 2013). Despite these caveats, at sites where $\delta^{18} \mathrm{O}_{\mathrm{c}}$ data are available on several planktonic foraminifer species, we could verify that LGM$\mathrm{LH} \delta^{18} \mathrm{O}_{\mathrm{sw}}$ anomalies derived from the different species were similar within error, thereby validating the above method. We infer that our method yields robust estimates of LGM-LH $\delta^{18} \mathrm{O}_{\mathrm{sw}}$ anomalies for the water column mixed layer.

We perform a careful estimation of the propagated error on the computed LGM-LH $\delta^{18} \mathrm{O}_{\text {sw }}$ anomalies (see Supplementary material) and obtain errors (defined as 1 sigma throughout the study) comprised between 0.35 and $0.95 \%$ (average error $\sim 0.50 \%$ ) on LGM-LH $\delta^{18} \mathrm{O}_{\text {sw }}$ anomalies derived from proxy-specific annual mean SST estimates, and slightly larger errors, comprised between 0.35 and $1.40 \%$ (average error $\sim 0.60 \%$ ), on LGM-LH $\delta^{18} \mathrm{O}_{\mathrm{sw}}$ anomalies derived from interpolated multiproxy annual mean SST estimates (Supplementary material). These error estimates should be considered as minima, given the difficulty in ascertaining all the uncertainties.

In addition, we note that in the laboratory, planktonic foraminifera $\delta^{18} \mathrm{O}$ and $\delta^{13} \mathrm{C}$ are influenced by the ambient carbonate ion concentration $\left(\left[\mathrm{CO}_{3}^{2-}\right]\right)$ of seawater (Spero et al., 1997) and field studies have confirmed the impact of the carbonate ion effect (CIE) on foraminifera shell geochemistry (Russell and Spero, 2000; Peeters et al., 2002). If we assume that the surface ocean was in equilibrium with LGM atmospheric $\mathrm{CO}_{2}$ concentration, then LGM surface ocean $\left[\mathrm{CO}_{3}^{2-}\right]$ would have been $60-100 \mu \mathrm{mol} \mathrm{kg}{ }^{-1}$ higher than the LH ocean (Lea et al., 1999). Such an increase in $\left[\mathrm{CO}_{3}^{2-}\right]$ would have produced a decrease in shell $\delta^{18} \mathrm{O}_{\mathrm{c}}$ of $0.07-0.25 \%$ depending on species and $\left[\mathrm{CO}_{3}^{2-}\right]$ change (Spero et al., 1997; Bijma et al., 1999). Because we do not account for this CIE correction here, one would need to increase the LGM-LH $\delta^{18} \mathrm{O}_{\text {sw }}$ anomalies by $0.07-0.25 \%$ to obtain CIE-corrected surface seawater $\delta^{18} \mathrm{O}$ change. Such a correction would therefore leave our conclusions unchanged.

In order to facilitate the interpretation of our results, we subtract the mean LGM ocean $\delta^{18} \mathrm{O}$ enrichment from significant LGM$\mathrm{LH} \delta^{18} \mathrm{O}_{\mathrm{sw}}$ anomalies before plotting them. The LGM mean ocean $\delta^{18} \mathrm{O}$ enrichment with respect to the $\mathrm{LH}$ represents the average effect of the change in global ice volume on seawater oxygen isotope geochemistry between these two periods. An LGM mean ocean $\delta^{18} \mathrm{O}$ enrichment of $1.0 \pm 0.1 \%$ has been established by different approaches (Schrag et al., 1996; Adkins et al., 2002; Duplessy et al., 2002; Schrag et al., 2002). The residual $\delta^{18} \mathrm{O}_{\text {sw }}$ anomalies (i.e. LGM-LH $\delta^{18} \mathrm{O}_{\mathrm{sw}}$ anomalies $-1 \%$ ) plotted in Figs. 2 to 4 and supplementary Figs. S1-S3 thus represent changes in surface water $\delta^{18} \mathrm{O}$ related to local changes in river runoff, evaporationprecipitation, or ocean circulation. Figs. 2-4 present for each ocean basin, annual mean proxy-specific SST anomalies and the corresponding residual $\delta^{18} \mathrm{O}_{\mathrm{sw}}$ anomalies, as well as interpolated multiproxy annual mean SST anomalies and corresponding residual $\delta^{18} \mathrm{O}_{\mathrm{sw}}$ anomalies.

\section{Results and discussion}

Data coverage is unfortunately sparse in large portions of the Pacific Ocean, and in the South Atlantic and Indian Oceans (Fig. 1). In the following, we thus focus on regional changes in a limited number of areas.

\subsection{Indian Ocean and South China Sea}

Annual mean SST reconstructed from LGM planktonic foraminifer counts are close to modern values in the northern tropical Indian Ocean, $0.7-2.4^{\circ} \mathrm{C}$ lower than modern values in the southern tropical Indian Ocean, and $0.4-2.0^{\circ} \mathrm{C}$ lower than modern values in the South China Sea (SCS) (Fig. 2B). LGM SST derived from alkenone unsaturation ratios $\mathrm{U}^{\mathrm{K}^{\prime}} 37$ are comparable to foraminifer-based SST estimates in the southern tropical Indian Ocean, but significantly lower elsewhere, reaching temperatures $3{ }^{\circ} \mathrm{C}$ lower than modern values in the Bay of Bengal and Arabian Sea, and about $4{ }^{\circ} \mathrm{C}$ lower than modern values in the SCS (Fig. 2D). In the area where LGM planktonic foraminifer $\mathrm{Mg} / \mathrm{Ca}$ SST estimates are available, just north of Australia, these are even lower than those derived from $\mathrm{U}^{\mathrm{K}^{\prime}}{ }_{37}$, reaching temperatures $3.0-3.6{ }^{\circ} \mathrm{C}$ lower than modern values (Fig. 2C). SST anomalies computed by interpolation of MARGO multiproxy gridded field are comprised within the range of SST anomalies provided by the different proxies, as expected (Fig. 2A).

Except for one site in the Mozambique Channel, annual mean residual $\delta^{18} \mathrm{O}_{\mathrm{sw}}$ anomalies in the tropical Indian Ocean are positive, irrespective of the specific SST estimates used to compute them (Fig. 2 and S1). The average tropical Indian Ocean annual mean residual $\delta^{18} \mathrm{O}_{\mathrm{sw}}$ anomaly derived from alkenone $\mathrm{U}^{\mathrm{K}^{\prime}} 37$ or multiproxy SST is $\sim+0.4 \%$, and that derived from foraminifer SST is $\sim+0.6 \%$. This increase in local surface water $\delta^{18} \mathrm{O}$ at the LGM with respect to the LH could reflect either a decrease in precipitation over the region, or a change in the advection of salty surface waters into or out of the region. A reduction in precipitation at the LGM compared to the present is supported by pollen-based precipitation reconstructions over eastern Africa (Bartlein et al., 2011). There are no

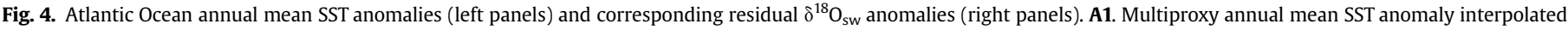

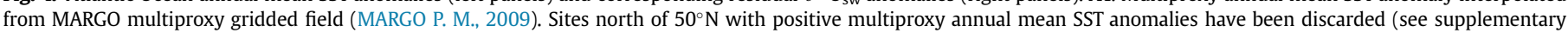

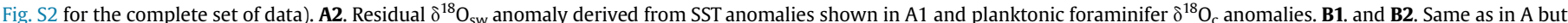

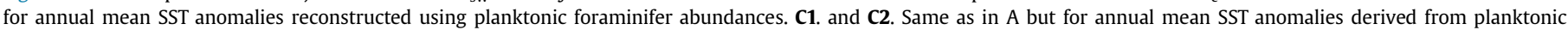

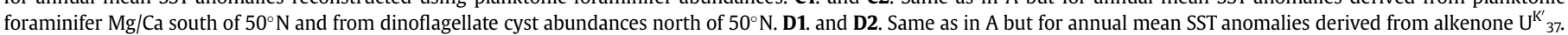


pollen reconstructions for India and western Asia, but grain size analyses of sediment from the Arabian Sea have been interpreted as indicating reduced precipitation during the LGM with respect to the LH (Caley et al., 2011b). In addition, several studies have shown that the Agulhas leakage of warm and salty surface waters from the low latitude Indian Ocean into the South Atlantic around South Africa was reduced during glacials with respect to interglacials (Peeters et al., 2004; Caley et al., 2011a), thereby resulting in the retention of salty surface waters in the tropical Indian Ocean during glacials. Positive annual mean $\delta^{18} \mathrm{O}_{\mathrm{sw}}$ anomalies in the tropical Indian Ocean could thus result from the combination of reduced precipitation and reduced export of salty surface waters into the Atlantic Ocean.

It is noteworthy that numerical simulations of $\delta^{18} \mathrm{O}_{\mathrm{sw}}$ during the LGM obtained with isotope-enabled coupled climate models produce positive $\delta^{18} \mathrm{O}_{\mathrm{sw}}$ anomalies of 0 to $+0.3 \%$ in the Arabian Sea, and +0.2 to $+0.3 \%$ in the Bay of Bengal (Caley et al., 2014; Ullman et al., 2014) after correcting for LGM ice volume, in excellent agreement with our estimates.

In the SCS, two of the three sites with alkenone $\mathrm{U}^{\mathrm{K}^{\prime}} 37$ data yield $\delta^{18} \mathrm{O}_{\mathrm{sw}}$ anomalies smaller than the corresponding propagated error. Hence, only residual $\delta^{18} \mathrm{O}_{\mathrm{sw}}$ anomalies computed from foraminifer and multiproxy SST anomalies are in sufficient numbers to provide an interpretable picture. These two approaches yield residual $\delta^{18} \mathrm{O}_{\text {sw }}$ anomalies between $\sim-0.3$ and $\sim+0.4 \%$, suggesting little change in precipitation, or surface advection in the SCS during the LGM with respect to the LH. Complimentary reconstructions of SCS regional hydrology also produce conflicting results. For instance, whereas Chinese speleothem $\delta^{18} \mathrm{O}$ records (Cheng et al., 2009) indicate a reduction in precipitation north of the SCS during the LGM, other studies indicate enhanced monsoon rainfall on land leading to increased river discharge into the SCS during the LGM with respect to the present (Colin et al., 2010).

\subsection{Pacific Ocean}

$\mathrm{Mg} / \mathrm{Ca}$ SST estimates are available from 9 sites across the western and eastern equatorial Pacific and one site East of New Zealand. All data from this proxy indicate that LGM SST was $1-3^{\circ} \mathrm{C}$ lower than at present (Fig. $3 \mathrm{C}$ ). There are only three locations in the Pacific Ocean where annual mean SST reconstructions are based on multiple proxies: Hawaii, where reconstructed SST anomalies based on planktonic foraminifer counts and alkenones are consistent, the Galapagos in the eastern equatorial Pacific, and the southwest Pacific to the east of New Zealand, where SST anomalies derived from planktonic foraminifer counts $\left(-10.6 \pm 1.3^{\circ} \mathrm{C}\right.$ and $-8.2 \pm 1.3^{\circ} \mathrm{C}$, respectively) and $\mathrm{Mg} / \mathrm{Ca}\left(-1.5 \pm 1.5^{\circ} \mathrm{C}\right.$ and $-2.7 \pm 1.5^{\circ} \mathrm{C}$, respectively) are very far apart (Fig. 3). The overall picture of interpolated multiproxy SST anomalies shows LGM SSTs $0.9-3.6{ }^{\circ} \mathrm{C}$ lower than at present in the equatorial and north Pacific, with the exception of the Northwest Pacific margin and Japan Sea where LGM annual mean SSTs were $0.6-4.7^{\circ} \mathrm{C}$ higher than at present (MARGO P. M., 2009) (Fig. 3A). However, the largest positive anomalies reconstructed north of Japan are based mainly on alkenone $\mathrm{U}^{\mathrm{K}^{\prime}}{ }_{37}$ and might not be true annual mean SST anomalies since the seasonality of the alkenone production could have changed through time (Minoshima et al., 2007; MARGO P. M., 2009). In the following, we do not discuss data from north of Japan, which are characterized by very high computed annual mean residual $\delta^{18} \mathrm{O}_{\text {sw }}$ anomalies.

Although there is only sparse data coverage in the central Pacific, annual mean residual $\delta^{18} \mathrm{O}_{\mathrm{sw}}$ anomalies derived from interpolated multiproxy SST appear to indicate that surface water $\delta^{18} \mathrm{O}$ was $\sim 0.3 \%$ lower than at present in the central North Pacific and higher than at present on the western and eastern margins of the North Pacific. We obtain an average $\delta^{18} \mathrm{O}_{\mathrm{sw}}$ anomaly of $+1.0 \%$ along the Californian coast, and of $+0.6 \%$ south of Japan (Fig. 3). These high positive residual $\delta^{18} \mathrm{O}_{\mathrm{sw}}$ anomalies values suggest reduced runoff due to drier conditions along the adjacent coasts during the LGM and/or advection of salty waters into these regions. Pollenbased reconstructions of LGM precipitation indicate drier conditions in western North America, just south of the Laurentide icesheet (at $\sim 50^{\circ} \mathrm{N}$ ), and wetter conditions further south, down to $\sim 30^{\circ} \mathrm{N}$ (Thompson and Anderson, 2000; Huang et al., 2001; Bartlein et al., 2011), but data are sparse south of $30^{\circ} \mathrm{N}$. Pollen-based reconstructions of LGM precipitation are almost non-existent in eastern Asia besides one site in Japan showing drier conditions than at present (Bartlein et al., 2011). However, even if climatic conditions on the western and eastern sides of the North Pacific were indeed drier during the LGM, a change in the precipitation-evaporation budget and runoff alone could hardly explain residual $\delta^{18} \mathrm{O}_{\mathrm{sw}}$ anomalies as large as +0.6 or $+1.0 \%$ in coastal waters that are in direct connection with the open ocean. These large anomalies instead very likely indicate a change in surface currents between the LH and the LGM.

At present, the Kuroshio western boundary current carries warm and salty equatorial surface waters northward through the East China Sea (ECS) and along Japan eastern margin up to $\sim 35^{\circ} \mathrm{N}$ where it diverts eastward to form the northern limb of the North Pacific subtropical gyre. Paleoceanographic studies have shown that during the LGM the Kuroshio path was restricted to lower latitudes and did not enter the ECS (Ujiié et al., 2003). The increase in LGM surface water temperature and $\delta^{18} \mathrm{O}$ at the sites located south of Japan and just east of the ECS could therefore be explained by the Kuroshio flowing above the sites, or nearer to these sites during the LGM. Interestingly, $N$. pachyderma $(\mathrm{s}) \delta^{18} \mathrm{O}_{\mathrm{c}}$ data from the Japan Sea record values that are 1.7\% lower during the LGM than during the LH (Gorbarenko and Southon, 2000). These data produce a large negative residual $\delta^{18} \mathrm{O}_{\mathrm{sw}}$ anomaly $(-2.6 \%)$ at that site indicating a large decrease in surface water $\delta^{18} \mathrm{O}$ in the Japan Sea. These data suggest that continental runoff largely exceeded evaporation in this area during the LGM, likely due to the quasiisolated nature of the Japan Sea relative to the open Pacific as a consequence of sea level dropping to depths below the sills that underlie the pathways into the region (Oba and Irino, 2012).

In the modern ocean, the California current forms the eastern limb of the North Pacific subtropical gyre that advects cold and relatively ${ }^{18} \mathrm{O}$-depleted sub-Arctic surface waters southward along the western coast of North America. Moreover, extensive upwelling of sub-surface waters currently occurs along the California coast driven by northeasterly winds (Huyer, 1983). Our results show that LGM surface waters along the California coast were characterized by both lower SSTs and higher $\delta^{18} \mathrm{O}_{\text {sw }}$ values than during the LH. A study based on a latitudinal transect of cores along the West American coast shows that the California current was strongly reduced during glacial maxima (Herbert et al., 2001). Other studies suggest that upwelling was also reduced during the LGM relative to today (Dean et al., 1997; Ortiz et al., 1997). At present, $\delta^{18} \mathrm{O}_{\mathrm{sw}}$ values along the Californian coast are $\sim-0.3 \%$, whereas $\delta^{18} \mathrm{O}_{\mathrm{sw}}$ reaches +0.4 to $+0.6 \%$ in the North Pacific subtropical gyre (Schmidt et al., 1999). An annual mean residual $\delta^{18} \mathrm{O}_{\mathrm{sw}}$ anomaly of $+1.0 \%$ is thus consistent with reduced upwelling and a higher proportion of surface waters from the North Pacific subtropical gyre being entrained in the surface waters off California during the LGM than during the $\mathrm{LH}$.

In the equatorial Pacific, annual mean residual $\delta^{18} \mathrm{O}_{\mathrm{sw}}$ anomalies are not markedly different from zero, suggesting no significant change with respect to modern conditions. The sole significant $\delta^{18} \mathrm{O}_{\mathrm{sw}}$ anomaly computed in the South Pacific is derived from foraminifer SST at $\sim 45^{\circ} \mathrm{S}$ east of New Zealand, with an estimated annual mean SST anomaly of $-8{ }^{\circ} \mathrm{C}$ and computed annual mean 
residual $\delta^{18} \mathrm{O}_{\mathrm{sw}}$ anomaly of $-2 \%$. These values are consistent with a northward shift of the Southern Ocean surface temperature fronts (Howard and Prell, 1992), such that cooler and fresher waters were found at that site during the LGM compared to the LH.

\subsection{Atlantic Ocean}

There are large discrepancies among reconstructed annual mean SST anomalies based on separate proxies in the northern North Atlantic and Nordic Seas (MARGO P. M., 2009). North of $\sim 45^{\circ} \mathrm{N}$, reconstructed annual mean SST anomalies based on planktonic foraminifer abundances range between -9 and $-11{ }^{\circ} \mathrm{C}$, whereas alkenone $\mathrm{U}^{\mathrm{K}^{\prime}}{ }_{37}$ and dinoflagellate cyst abundances yield positive anomalies in most locations, reaching +5 to $+6{ }^{\circ} \mathrm{C}$ in the latter case in the Nordic Seas (supplementary Fig. S2). However, it is unlikely that LGM annual mean SSTs were higher than at present in the high latitude North Atlantic since polar amplification leads to larger LGM-LH surface temperature anomalies in those regions than at lower latitudes (Masson-Delmotte et al., 2006). Moreover, elevated LGM SSTs derived from dinoflagellate cyst abundances have been shown to correspond to "no-analog" situations (de Vernal et al., 2006), and positive SST anomalies derived from alkenone $\mathrm{U}^{\mathrm{K}^{\prime}}{ }_{37}$ in the northern North Atlantic have been suggested to result from a bias in SST reconstructions at very low temperatures (Conte et al., 2006) or advection of the light alkenone carriers over large distances (Mollenhauer et al., 2006). More generally, alkenone $\mathrm{U}^{\mathrm{K}^{\prime}}{ }_{37}$ and dinoflagellate cyst abundances likely record temperature signals that correspond to different seasons and water depths than those recorded by planktonic foraminifer in this region (de Vernal et al., 2005). In the subsequent discussion, we will thus only retain the high latitude sites for which negative SST anomalies were reconstructed (Fig. 4 and supplementary Fig. S3).

Along the Iberian margin and in the western tropical Atlantic, the different SST proxies yield consistent anomalies of -2 to $-4{ }^{\circ} \mathrm{C}$ (Fig. 4). In the Mediterranean Sea, only foraminifer SST reconstructions are available. These reconstructions yield LGM SSTs that are $7-10{ }^{\circ} \mathrm{C}$ lower than at present in the western Mediterranean Sea, and $\sim 5^{\circ} \mathrm{C}$ lower than at present in the Adriatic Sea. In the central equatorial Atlantic and eastern South Atlantic, all separate proxies yield negative anomalies although SST anomalies derived from planktonic foraminifer counts are much more negative $\left(-6{ }^{\circ} \mathrm{C}\right.$ in the central equatorial Atlantic and $-11.6^{\circ} \mathrm{C}$ off Namibia) than $\mathrm{Mg} / \mathrm{Ca}$-based $\left(-3^{\circ} \mathrm{C}\right.$ and $-3.6^{\circ} \mathrm{C}$, respectively) and alkenone-based $\left(-2{ }^{\circ} \mathrm{C}\right.$ and $-1{ }^{\circ} \mathrm{C}$, respectively) SST anomalies (Fig. 4). It should be noted that low confidence was assigned to SST estimates based on planktonic foraminifer counts in sites located along South-West Africa (Kucera et al., 2005b). This area is indeed characterized by upwelling of cold subsurface waters that strongly influences the distribution of planktonic foraminifer species, leading to a lack of analogs and large offsets (up to $4{ }^{\circ} \mathrm{C}$ ) among the different statistical techniques (Kucera et al., 2005b).

Mapping annual mean residual $\delta^{18} \mathrm{O}_{\mathrm{sw}}$ anomalies computed from interpolated multiproxy SST (Fig. 4) reveals positive residual $\delta^{18} \mathrm{O}_{\text {sw }}$ anomalies in the open northern North Atlantic. However, this picture contrasts with the large negative residual $\delta^{18} \mathrm{O}_{\mathrm{sw}}$ anomalies of $\sim-1.7 \%$ computed from foraminifer SSTs around $50^{\circ} \mathrm{N}$ (Fig. 4B and supplementary Fig. S3). These large negative residual $\delta^{18} \mathrm{O}_{\mathrm{sw}}$ anomalies are consistent with a southward shift of the polar front such that fresher and colder surface waters were present at these sites during the LGM with respect to the LH. North of these sites, the large positive residual $\delta^{18} \mathrm{O}_{\mathrm{sw}}$ anomalies $(+0.6$ to $+1.5 \%$ ) computed from multiproxy SST anomalies result from unrealistically small negative multiproxy SST anomalies due to the impact of alkenone $\mathrm{U}^{\mathrm{K}^{\prime}} 37$ and dinoflagellate cyst positive annual mean SST estimates on the weighted multiproxy average. We thus consider that the positive residual $\delta^{18} \mathrm{O}_{\mathrm{sw}}$ anomalies computed from interpolated multiproxy SST estimates in the northern North Atlantic are not realistic. It is interesting to note that isotopeenabled couples climate models produce negative $\delta^{18} \mathrm{O}_{\mathrm{sw}}$ anomalies north of $40^{\circ} \mathrm{N}$ in the North Atlantic, reaching - $0.3 \%$ (Ullman et al., 2014) to $\sim-0.7 \%$ (Caley et al., 2014) after correction for the LGM ice-sheet contribution. These modeling results lend support to our decision to discard positive residual $\delta^{18} \mathrm{O}_{\mathrm{sw}}$ anomalies computed from alkenone $\mathrm{U}^{\mathrm{K}^{\prime}}{ }_{37}$ and dinoflagellate cyst SST estimates north of $50^{\circ} \mathrm{N}$.

Consistent patterns emerge at lower latitudes in the open Atlantic Ocean. Positive residual $\delta^{18} \mathrm{O}_{\mathrm{sw}}$ anomalies are computed based on all separate SST proxies on the Iberian margin ranging from +0.1 to $+0.8 \%$, with average values of $+0.3 \%$ and $+0.2 \%$ for residual $\delta^{18} \mathrm{O}_{\mathrm{sw}}$ anomalies computed from foraminifer and alkenone $\mathrm{U}^{\mathrm{K}^{\prime}}{ }_{37}$ SST, respectively (Fig. 4). In contrast, residual $\delta^{18} \mathrm{O}_{\mathrm{sw}}$ anomalies computed in the western Mediterranean Sea are negative (average residual $\delta^{18} \mathrm{O}_{\mathrm{sw}}$ anomaly $\sim-0.4 \%$ ). At present, $\delta^{18} \mathrm{O}_{\mathrm{sw}}$ is about $+0.9 \%$ on the Iberian Margin and +1.3 to $+1.6 \%$ in western Mediterranean Sea (Schmidt et al., 1999). Residual $\delta^{18} \mathrm{O}_{\text {sw }}$ anomalies thus indicate that the gradient in surface water $\delta^{18} \mathrm{O}$ between these two regions was attenuated during the LGM with respect to today. Previous studies have indicated that this situation was likely the result of a significant reorganization of surface water circulation in the western Mediterranean Sea and that the inflow of Atlantic water was reduced at the LGM with respect to present day (Rohling, 1999; Rogerson et al., 2010). Interestingly, residual $\delta^{18} \mathrm{O}_{\mathrm{sw}}$ anomalies computed in the Adriatic Sea are positive (average residual $\delta^{18} \mathrm{O}_{\text {sw }}$ anomaly $\sim+0.4 \%$ ), pointing to decreased runoff east of the Alps during the LGM with respect to the LH.

The positive residual $\delta^{18} \mathrm{O}_{\mathrm{sw}}$ anomalies computed along the Iberian margin are consistent with pollen-based reconstructions of LGM precipitation indicating overall drier conditions in the Mediterranean region during the LGM than at present (Bartlein et al., 2011). Positive residual $\delta^{18} \mathrm{O}_{\mathrm{sw}}$ anomalies along the Iberian margin are also consistent with surface conditions in the open tropical North Atlantic, as residual $\delta^{18} \mathrm{O}_{\text {sw }}$ anomalies between 0 and $20^{\circ} \mathrm{N}$ are positive and range between +0.2 and $+0.5 \%$. This pattern is in line with studies indicating an increase in salinity of surface waters in the tropical North Atlantic (Carlson et al., 2008) and Caribbean (Schmidt et al., 2004) during the LGM with respect to the LH. Such a pattern can be attributed to a slowdown of the advection of salty surface waters towards the high northern latitudes (Carlson et al., 2008), a southward displacement of the intertropical convergence zone (ITCZ) (McGee et al., 2014), or a combination of both.

In the tropical South Atlantic and along the Brazilian margin, residual $\delta^{18} \mathrm{O}_{\mathrm{sw}}$ anomalies derived from foraminifer SST are positive too, but lower than in the tropical North Atlantic, with values close to $+0.2 \%$. There are only 2 sites where SST estimates based on different proxies are available: (i) on the northern Brazilian margin, the annual mean residual $\delta^{18} \mathrm{O}_{\mathrm{sw}}$ anomalies computed from alkenone $\mathrm{U}^{\mathrm{K}^{\prime}} 37$ and $\mathrm{Mg} / \mathrm{Ca}$ SST are negative and equal to $\sim-0.1$ and $\sim$ $-0.3 \%$ respectively. The residual $\delta^{18} \mathrm{O}_{\text {sw }}$ anomalies computed from foraminifer SST in two neighboring sites, however, yield an average residual $\delta^{18} \mathrm{O}_{\mathrm{sw}}$ anomaly of $+0.3 \%$. (ii) Off southern Brazil, the residual $\delta^{18} \mathrm{O}_{\text {sw }}$ anomaly computed from alkenone $\mathrm{U}^{\mathrm{K}^{\prime}}{ }_{37}$ SST is $0.0 \%$, whereas that computed from foraminifer SST is $+0.3 \%$. The sign of computed residual $\delta^{18} \mathrm{O}_{\mathrm{sw}}$ anomalies in the tropical South Atlantic and along the Brazilian margin thus depends on the type of SST proxy used, thereby preventing us to identify a robust pattern.

In the central equatorial Atlantic, negative residual $\delta^{18} \mathrm{O}_{\mathrm{sw}}$ anomalies of $\sim-0.1$ and $\sim-0.3 \%$ are computed from alkenone $\mathrm{U}^{\mathrm{K}^{\prime} \mathrm{W}}$ and $\mathrm{Mg} / \mathrm{Ca}$ SST respectively. This points to a more southerly position of the ITCZ during the LGM than during the LH, as indicated by paleoclimatic records (McGee et al., 2014). 
Finally, a very large positive residual $\delta^{18} \mathrm{O}_{\text {sw }}$ anomaly is computed for the South Atlantic off Namibia, reaching $+1.0 \%$ for $\mathrm{Mg} / \mathrm{Ca}$ SST and $+1.6 \%$ for alkenone $U^{K^{\prime}} 37$ SST. Drier conditions over western South Africa during the LGM have been proposed in a number of studies based on pollens (Shi et al., 1998), clay composition (Gingele, 1996) or leaf-wax isotopic composition (Collins et al., 2013). However, a change in the precipitation-evaporation budget and runoff alone can not explain residual $\delta^{18} \mathrm{O}_{\mathrm{sw}}$ anomalies as large as +1.0 to $+1.6 \%$ in coastal waters that are in direct connection with the open ocean. MARGO multiproxy SST reconstructions indicate that LGM annual mean SSTs along the south-west African coast were $2-4{ }^{\circ} \mathrm{C}$ lower than at present (Fig. 4). These low SSTs were attributed to enhanced upwelling of colder water along the continental margin or enhanced advection of subpolar waters into the Benguela current (MARGO P. M., 2009). Our results indicate that the latter hypothesis can be discarded since subpolar surface waters are characterized by lower $\delta^{18} \mathrm{O}$ values than those to the north. In the modern ocean, the main source of upwelled waters in the Namibian region is Eastern South Atlantic Central Water (ESACW) from 150 to $500 \mathrm{~m}$ depth (Shannon, 1985). At present, ESACW originates near the Cape of Good Hope and ESACW deeper layers are partly composed of cold Antarctic Intermediate Water from up to $500 \mathrm{~m}$ depth and SubAntarctic waters transported equatorward out of the Antarctic Circumpolar Current (Garzoli and Gordon, 1996). Our results suggest that upwelled waters were colder and ${ }^{18} \mathrm{O}$-enriched relative to the modern ocean. Such waters could originate from a mixture of recirculated South Atlantic central waters originating from lower latitudes, Glacial North Atlantic intermediate water and circumpolar deep water. The latter two water masses could indeed partly feed upwelling along the south western African coast as a result of the northward displacement of the Antarctic divergence together with the equatorward migration of the Southern Ocean surface temperature fronts at the LGM (Howard and Prell, 1992; Peeters et al., 2004). Clearly, more data from the South Atlantic are necessary to constrain the water sources for this anomaly.

\section{Conclusions}

The present study provides the first set of $\delta^{18} \mathrm{O}_{\mathrm{sw}}$ anomalies computed in a systematic way from homogenous data sets with rigorous age control. Examination of the estimated $\delta^{18} \mathrm{O}_{\mathrm{sw}}$ anomalies on a regional scale brings new constraints on the knowledge of the LGM surface ocean, highlighting which changes in surface currents and hydrological cycle are consistent with both planktonic isotopic data and reconstructed SST:

(1) Annual mean residual $\delta^{18} \mathrm{O}_{s w}$ anomalies in the tropical Indian Ocean are generally positive, with average $\mathrm{LGM} \delta^{18} \mathrm{O}_{\mathrm{sw}}$ values $0.4-0.6 \%$ higher than $\mathrm{LH}$ values. This increase in $\delta^{18} \mathrm{O}_{\mathrm{sw}}$ most likely results from the combined effect of decreased precipitation over the adjacent continental regions, and reduced Agulhas leakage of warm and salty surface waters from the Indian into the Atlantic Ocean during glacials.

(2) Annual mean residual $\delta^{18} \mathrm{O}_{\mathrm{sw}}$ anomalies in the North Pacific exhibit high positive values South-West of Japan $(\sim+0.6 \%)$ and along the Californian coast $(\sim+1.0 \%$ ). We interpret these large anomalies as mainly reflecting a change in surface currents between the LGM and the LH. On the one hand, higher LGM surface water temperature and $\delta^{18} \mathrm{O}$ than during the LH at the two sites located south of Japan could be explained by the Kuroshio Current flowing nearer to these sites during the LGM. On the other hand, a residual $\delta^{18} \mathrm{O}_{\mathrm{sw}}$ anomaly of $+1.0 \%$ along the Californian coast is consistent with reduced upwelling and a strongly reduced California current leading to a higher proportion of surface waters from the North Pacific subtropical gyre in surface waters off California during the LGM than during the $\mathrm{LH}$.

(3) The sole data in the South Pacific yield a large negative residual $\delta^{18} \mathrm{O}_{\mathrm{sw}}$ anomaly $(-2.0 \%$ ) at a site located east of New Zealand and characterized by LGM SSTs $8{ }^{\circ} \mathrm{C}$ lower than at present. These values are consistent with previous studies indicating that Southern Ocean surface temperature fronts shifted northward by several degrees of latitude during the LGM.

(4) Our results in the South Atlantic indicate that surface waters along western South Africa were both colder and richer in ${ }^{18} \mathrm{O}$, with residual $\delta^{18} \mathrm{O}_{\mathrm{sw}}$ anomalies of +1.0 to $+1.6 \%$ off Namibia. We suggest that this is due to the northward migration of the Southern Ocean surface fronts and Antarctic divergence during the LGM leading to a higher proportion of a mixture of Glacial North Atlantic intermediate water and circumpolar deep water being entrained in the upwelled waters off Namibia at that time than at present.

(5) In the northern North Atlantic (north of $\sim 50^{\circ} \mathrm{N}$ ), a region characterized by large discrepancies between SST estimates based on different proxies (MARGO P. M., 2009), comparison of annual mean residual $\delta^{18} \mathrm{O}_{\mathrm{sw}}$ anomalies derived from different SST reconstructions shows that only SST estimates based on planktonic foraminifer counts yield seawater $\delta^{18} \mathrm{O}_{\mathrm{sw}}$ anomalies consistent with a southward shift of the polar front at the LGM relative to the $\mathrm{LH}$, as indicated by continental data (i.e. ice core or pollen data).

\section{Acknowledgments}

We are grateful to three anonymous reviewers for their helpful comments on an earlier vesion of this article, and to D.J. Ullman for providing us with quantified data from simulations recently published in Climate of the Past. C.W. is supported by the French Centre National de la Recherche Scientifique and Institut National des Sciences de l'Univers. Part of the new data have been generated in the framework of the European Science Foundation (ESF)/EUROMARC project RETRO. H.J.S. was supported by the U.S. National Science Foundation and the Alexander von Humboldt Foundation during the writing of this manuscript. This is LSCE contribution 5322 .

\section{Appendix A. Supplementary data}

Supplementary data related to this article can be found at http:// dx.doi.org/10.1016/j.quascirev.2014.09.020.

\section{References}

Adkins, J.F., McIntyre, K., Schrag, D.P., 2002. The salinity, temperature, and $\mathrm{d}^{18} \mathrm{O}$ of the glacial deep ocean. Science 298, 1769-1773.

Bartlein, P.J., Harrison, S.P., Brewer, S., Connor S., Davis, B.A.S., Gajewski, K., Guiot, J., Harrison-Prentice, T.I., Henderson, A., Peyron, O., Prentice, I.C., Scholze, M. Seppä, H., Shuman, B., Sugita, S., Thompson, R.S., Viau, A.E., Williams, J., Wu, H., 2011. Pollen-based continental climate reconstructions at 6 and 21 ka: a global synthesis. Clim. Dynam 37, 775-802.

Bijma, J., Spero, H.J., Lea, D.W., 1999. Reassessing foraminiferal stable isotopes: effects of seawater carbonate chemistry (experimental results). In: Fischer, G. Wefer, G. (Eds.), Use of Proxies in Paleoceanography: Examples from the South Atlantic. Springer-Verlag, Berlin, pp. 489-512.

Braconnot, P., Harrison, S.P., Kageyama, M., Bartlein, P.J., Masson-Delmotte, V., AbeOuchi, A., Otto-Bliesner, B., Zhao, Y., 2012. Evaluation of climate models using palaeoclimatic data. Nat. Clim. Change 2, 417-424.

Caley, T., Kim, J.-H., Malaizé, B., Giraudeau, J., Laepple, T., Caillon, N., Charlier, K., Rebaubier, H., Rossignol, L., Castaneda, I.S., Schouten, S., Sinninghe Damsté, J.S., 2011a. High-latitude obliquity as a dominant forcing in the Agulhas current system. Clim. Past 7, 1285-1296.

Caley, T., Malaizé, B., Zaragosi, S., Rossignol, L., Bourget, J., Eynaud, F., Martinez, P., Giraudeau, J., Charlier, K., Ellouz-Zimmermann, N., 2011b. New Arabian Sea 
records help decipher orbital timing of Indo-Asian monsoon. Earth Planet. Sci. Lett. 308, 433-444.

Caley, T., Roche, D.M., Waelbroeck, C., Michel, E., 2014. Constraining the Last Glacial Maximum climate by data-model (iLOVECLIM) comparison using oxygen stable isotopes. Clim. Past Discuss. 10, 105-148.

Carlson, A.E., Oppo, D.W., Came, R.E., LeGrande, A.N., Keigwin, L.D., Curry, W.B., 2008. Subtropical Atlantic salinity variability and Atlantic meridional circulation during the last deglaciation. Geology 991-994.

Cheng, H., Edwards, R.L., Broecker, W.S., Denton, G.H., Kong, X., Wang, Y., Zhang, R. Wang, X., 2009. Ice age terminations. Science 326, 248-252.

Colin, C., Siani, G., Sicre, M.-A., Liu, Z., 2010. Impact of the East Asian monsoon rainfall changes on the erosion of the Mekong River basin over the past 25,000 yr. Mar. Geol. 271, 84-92.

Collins, J.A., schefuss, E., Mulitza, S., Prange, M., Tharammal, W.M.,T., Paul, A., Wefer, G., 2013. Estimating the hydrogen isotopic composition of past precipitation using leaf-waxes from western Africa. Quat. Sci. Rev. 65, 88-101.

Conte, M.H., Sicre, M.-A., Rühlemann, C., Weber, J.C., Schulte, S., Schulz-Bull, D., Blanz, T., 2006. Global temperature calibration of the alkenone unsaturation index in surface waters and comparison with surface sediments. Geochem. Geophys. Geosyst. 7 (2) http://dx.doi.org/10.1029/2005GC001054.

de Vernal, A., Eynaud, F., Henry, M., Hillaire-Marcel, C., Londeix, L., Mangin, S. Matthiessen, J., Marret, F., Radi, T., Rochon, A., Solignac, S., Turon, J.-L., 2005. Reconstruction of sea-surface conditions at middle to high latitudes of the Northern Hemisphere during the Last Glacial Maximum (LGM) based on dinoflagellate cyst assemblages. Quat. Sci. Rev. 24, 897-924.

de Vernal, A., Rosell-Melé, A., Kucera, M., Hillaire-Marcel, C., Eynaud, F., Weinelt, M. Dokken, T., Kageyama, M., 2006. Comparing proxies for the reconstruction of LGM sea-surface conditions in the northern North Atlantic. Quat. Sci. Rev. 25, 2820-2834.

Dean, W.E., Gardner, J.V., Piper, D.Z., 1997. Inorganic geochemical indicators of glacial-interglacial changes in productivity and anoxia on the California continental margin. Geochim. Cosmochim. Acta 61 (21), 4507-4518.

Duplessy, J.-C., Labeyrie, L., Juillet-Leclerc, A., Maitre, F., Duprat, J., Sarnthein, M., 1991. Surface salinity reconstruction of the North Atlantic Ocean during the last glacial maximum. Oceanol. Acta 14 (4), 311-324.

Duplessy, J.C., Labeyrie, L., Waelbroeck, C., 2002. Constraints on the ocean oxygen isotopic enrichment between the last glacial maximum and the Holocene: paleoceanographic implications. Quat. Sci. Rev. 21 (1-3), 315-330.

Epstein, S., Mayeda, T., 1953. Variation of ${ }^{18} \mathrm{O}$ content of waters from natural sources. Geochim. Cosmochim. Acta 4, 213-224.

Fraile, I., Schulz, M., Mulitza, S., Merkel, U., Prange, M., Paul, A., 2009. Modeling the seasonal distribution of planktonic foraminifera during the Last Glacial Maximum. Paleoceanography 24, PA2216. http://dx.doi.org/10.1029/ 2008PA001686.

Garzoli, S.L., Gordon, A.L., 1996. Origins and variability of the Benguela Current. J. Of Geophys. Res. 101 (C1), 897-906.

Gingele, F.X., 1996. Holocene climatic optimum in Southwest Africa evidence from the marine clay mineral record. Palaeogeogr. Palaeoclimatol. Palaeoecol. 122, 77-87.

Gorbarenko, S.A., Southon, J.R., 2000. Detailed Japan Sea paleoceanography during the last 25 kyr: constraints from AMS dating and d180 of planktonic foraminifera. Palaeogeogr. Palaeoclimatol. Palaeoecol. 156, 177-193.

Herbert, T.D., Schuffert, J.D., Andreasen, D., Heusser, L., Lyle, M., Mix, A., Ravelo, A.C., Stott, L.D., Herguera, J.C., 2001. Collapse of the California current during glacia maxima linked to climate change on land. Science 293, 71-76.

Howard, W.R., Prell, W.L., 1992. Late Quaternary surface circulation of the Southern Indian Ocean and its relationship to orbital variations. Paleoceanography 7 (1), 79-117.

Huang, Y., Street-Perrott, F.A., Metcalfe, S.E., Brenner, M., Moreland, M., Freeman, K.H., 2001. Climate change as the dominant control on glacialinterglacial variations in C3 and C4 plant abundance. Science 293, 1647-1651.

Huyer, A., 1983. Coastal upwelling in the California current system. Prog. Oceanogr. 12, 259-284.

Kim, S.-T., O'Neil, J.R., 1997. Equilibrium and nonequilibrium oxygen isotope effects in synthetic carbonates. Geochim. Cosmochim. Acta 61 (16), 3461-3475.

Kucera, M., Rosell-Melé, A., Schneider, R., Waelbroeck, C., Weinelt, M., 2005a. Multiproxy approach for the reconstruction of the glacial ocean surface (MARGO). Quat. Sci. Rev. 24, 813-819.

Kucera, M., Weinelt, M., Kiefer, T., Pflaumann, U., Hayes, A., Weinelt, M., Chen, M.-T., Mix, A.C., Barrows, T.T., Cortijo, E., Duprat, J., Juggins, S., Waelbroeck, C., 2005b. Reconstruction of the glacial Atlantic and Pacific sea-surface temperatures from assemblages of planktonic foraminifera: multi-technique approach based on geographically constrained calibration datasets. Quat. Sci. Rev. 24, 951-998.

Lea, D.W., Bijma, J., Spero, H.J., Archer, D., 1999. Implications of a carbonate ion effect on shell carbon and oxygen isotopes for glacial ocean conditions. In: Fischer, G., Wefer, G. (Eds.), Use of Proxies in Paleoceanography - Examples from the South Atlantic. Springer-Verlag, Berlin, pp. 513-522.

MARGO Project Members, Waelbroeck, C., Paul, A., Kucera, M., Rosell-Melé, A Weinelt, M., Schneider, R., Mix, A.C., 2009. Constraints on the magnitude and patterns of ocean cooling at the Last Glacial Maximum. Nat. Geosci. 2, 127-132.
Masson-Delmotte, V., Kageyama, M., Braconnot, P., Charbit, S., Krinner, G., Ritz, C., Guilyardi, E., Jouzel, J., Abe-Ouchi, A., Crucifix, M., Gladstone, R.M., Hewitt, C.D., Kitoh, A., LeGrande, A.N., Marti, O., Merkel, U., Motoi, T., Ohgaito, R., OttoBliesner, B., Peltier, W.R., Ross, I., Valdes, P.J., Vettoretti, G., Weber, S.L., Wolk, F., Yu, Y., 2006. Past and future polar amplification of climate change: climate model intercomparisons and ice-core constraints. Clim. Dynam. 26, 513-529.

McGee, D., Donohoe, A., Marshall, J., Ferreira, D., 2014. Changes in ITCZ location and cross-equatorial heat transport at the Last Glacial Maximum, Heinrich Stadial 1, and the mid-Holocene. Earth Planet. Sci. Lett. 390, 69-79.

Minoshima, K., Kawahata, H., Ikehara, K., 2007. Changes in biological production in the mixed water region (MWR) of the northwestern North Pacific during the last 27 kyr. Palaeogeogr. Palaeoclimatol. Palaeoecol. 254, 430-447.

Mollenhauer, G., McManus, J.F., Benthien, A., Müller, P.J., Eglinton, T.I., 2006. Rapid lateral particle transport in the Argentine Basin: molecular $14 \mathrm{C}$ and 230Thxs evidence. Deep-Sea Res. I 53, 1224-1243.

O'Neil, J.R., Clayton, R.N., Mayeda, T.K., 1969. Oxygen isotope fractionation in divalent metal carbonates. J. Chem. Phys. 51, 5547-5558.

Oba, T., Irino, T., 2012. Sea level at the Last Glacial Maximum, constrained by oxygen isotopic curves of planktonic foraminifera in the Japan Sea. J. Quat. Sci. 27 (9), 941-947.

Ortiz, J., Mix, A., Hostetler, S., Kashgarian, M., 1997. The California current of the last glacial maximum: reconstruction at $42 \varnothing \mathrm{N}$ based on multiple proxies. Paleoceanography 12 (2), 191-205.

Peeters, F.J.C., Brummer, G.-J.A., Ganssen, G., 2002. The effect of upwelling on the distribution and stable isotope composition of Globigerina bulloides and Globigerinoides ruber (planktic foraminifera) in modern surface waters of the NW Arabian Sea. Glob. Planet. Change 34, 269-291.

Peeters, F.J.C., Acheson, R., Brummer, G.-J.A., Ruijter, W.P.M., Schneider, R.R., Ganssen, G.M., Ufkes, E., Kroon, D., 2004. Vigorous exchange between the Indian and Atlantic oceans at the end of the past five glacial periods. Nature 430, 661-665.

Rogerson, M., Colmenero-Hidalgo, E., Levine, R.C., Rohling, E.J., Voelker, A.H.L., Bigg, G.R., Schönfeld, J., Cacho, I., Sierro, F.J., Löwemark, L., Reguera, M.I., de Abreu, L., Garrick, K., 2010. Enhanced Mediterranean-Atlantic exchange during Atlantic freshening phases. Geochem. Geophys. Geosyst. 11 (8) http:// dx.doi.org/10.1029/2009GC002931.

Rohling, E.J., Bigg, G.R., 1998. Paleosalinity and d180: a critical assessment. J. Geophys. Res. 103, 1307-1318.

Rohling, E.J., 1999. Environmental control on Mediterranean salinity and d180. Paleoceanography 14 (6), 706-715.

Rosell-Melé, A., Prahl, F.G., 2013. Seasonality of UK'37 temperature estimates as inferred from sediment trap data. Quat. Sci. Rev. 72, 128-136.

Russell, A.D., Spero, H.J., 2000. Field examination of the oceanic carbonate ion effect on planktonic foraminiferal stable isotopes. Paleoceanography 16 (1), 43-52.

Schmidt, G.A., Bigg, G.R., Rohling, E.J., 1999. Global Seawater Oxygen-18 Database. http://www.giss.nasa.gov/data/o18data/.

Schmidt, M.W., Spero, H.J., Lea, D.W., 2004. Links between salinity variation in the Caribbean and North Atlantic thermohaline circulation. Nature 428, 160-163.

Schrag, D.P., Hampt, G., Murray, D.W., 1996. Pore fluid constraints on the temperature and oxygen isotopic composition of the glacial ocean. Science 272, 1930-1932.

Schrag, D.P., Adkins, J.F., McIntyre, K., Alexander, J.L., Hodell, D.A., Charles, C.D., McManus, J.F., 2002. The oxygen isotopic composition of seawater during the Last Glacial Maximum. Quat. Sci. Rev. 21, 331-342.

Shannon, L.V., 1985. The Benguela Ecosystem, I. Evolution of the Benguela, physical features and processes. Oceanogr. Mar. Biol. 23, 105-182.

Shi, N., Dupont, L.M., Beug, H.-J., Schneider, R., 1998. Vegetation and climate changes during the last 21000 years in S.W. Africa based on a marine pollen record. Veg. Hist. Archaeobot. 7, 127-140.

Spero, H.J., Bijma, J., Lea, D.W., Bemis, B.E., 1997. Effect of seawater carbonate concentration on foraminiferal carbon and oxygen isotopes. Nature 390, 497-500.

Telford, R.J., Li, C., Kucera, M., 2013. Mismatch between the depth habitat of planktonic foraminifera and the calibration depth of SST transfer functions may bias reconstructions. Clim. Past 9, 859-870.

Thompson, R.S., Anderson, K.H., 2000. Biomes of western North America at 18,000, 6,000 and 0 14C yr BP reconstructed from pollen and packrat midden data. J. Biogeogr. 27, 555-584.

Ujiié, Y., Ujiié, H., Taira, A., Kakamura, T., Oguri, K., 2003. Spatial and temporal variability of surface water in the Kuroshio source region, Pacific Ocean, over the past 21,000 years: evidence from planktonic foraminifera. Mar. Micropaleontol. 49, 335-364.

Ullman, D.J., LeGrande, A.N., Carlson, A.E., Anslow, F.S., Licciardi, J.M., 2014. Assessing the impact of Laurentide Ice Sheet topography on glacial climate. Clim. Past 10, 487-507.

Waelbroeck, C., Mulitza, S., Spero, H., Dokken, T., Kiefer, T., Cortijo, E., 2005. A global compilation of late Holocene planktonic foraminiferal d180: relationship between surface water temperature and d180. Quat. Sci. Rev. 24, 853-868. 